\title{
Conservation Science Research at the Museum: Development of Carbon Dioxide Treatment for Museum Collection
}

\author{
Shingo Hidaka
}

\begin{abstract}
The development of an enclosure-type insecticidal treatment for ethnographic/folklore artifacts using carbon dioxide is described. After the successful installation of the system, the technique was applied on a larger scale using a special enclosure-type bag (11.5 $\mathrm{m}$ in length, $10 \mathrm{~m}$ in width, and $2 \mathrm{~m}$ in height). Since one of the preconditions for development of the system was that the treatment procedures could be performed by museum staff, close attention was paid to worker safety. Other challenges faced were to: minimize the decrease in humidity inside the bag when carbon dioxide is supplied; achieve a uniform distribution of carbon dioxide concentration in a large-scale treatment facility; and establish supplementary methods for killing insects that resist by carbon dioxide treatment (e.g. longicorn beetles).
\end{abstract}

\section{Introduction}

Methyl bromide was widely used in Japan for the insecticidal treatment of cultural properties in the past, but it is no longer permitted for use because of a resolution made in the Meeting of the Parties to the Montreal Protocol to totally ban the use of methyl bromide at the end of 2004. Thus, there is urgent need to accelerate the practical application and implementation of a new insecticidal treatment method alternative to the method using methyl bromide for preserving cultural properties. In this regard, research has been conducted on the insecticidal treatment method using carbon dioxide, a gas harmless to people and the environment, and the low-oxygen treatment method using an inert gas such as nitrogen, in an effort to establish a method alternative to the fumigation method using methyl bromide preparations that was commonly performed in Japan previously. There are a number of reports introducing actual cases of using these new methods at museums.

\footnotetext{
S. Hidaka $(\bowtie)$

National Museum of Ethnology, Senri Expo Park, Suita, Osaka 565-8511, Japan

e-mail: s-hidaka@idc.minpaku.ac.jp 
The author has been working at the Gangoji Institute for Research of Cultural Property since 1994, and specializes in the development of technologies for the preservation of primarily folklore artifacts. Folklore artifacts are made of plant materials, most often wood, so these cultural properties are prone to insect damage. Thus, insecticidal treatment is an important process required for preserving folklore artifacts. In view of this, the author examined methods of insecticidal treatment for mainly folklore artifacts that can replace the method using methyl bromide. It should be noted that the gas fumigation method was excluded from examination in order to align with the globally growing concerns for people and the environment (Strang and Kigawa 2011; Kigawa and Strang 2011).

Since there are huge numbers of folklore artifacts subject to insecticidal treatment, the treatment must be inexpensive to perform, be applicable to objects of various sizes and shapes, and allow mass processing of artifacts. The author developed an enclosure-type insecticidal treatment system using carbon dioxide, which satisfies all these requirements, and put it into practical use at the National Museum of Ethnology (Minpaku).

This paper introduces the case of insecticidal treatment of folklore artifacts using carbon dioxide, a method developed and practiced by the author et al.

\section{Development of an Enclosure-Type Insecticidal Treatment System Using Carbon Dioxide}

The author began experimental insecticidal treatments using carbon dioxide in earnest in 2000. To develop the treatment system, experiments were conducted four times. The scale of the experiments was determined in accordance with the size and quantity of the target folklore artifacts in order to accurately simulate the actual processing conditions. The first, second, and fourth experiment sessions were held at the Gangoji Institute for Research of Cultural Property (Fig. 1), and the third experiment session was conducted in the repository at the Japan Footwear Museum, courtesy of the Museum.

The sheets (carbon dioxide permeability: $4 \mathrm{ml} /\left(\mathrm{m}^{2}\right.$.days.atm)) used for the experiments were barrier cloth sheets laminated with a layer of ethylene-vinyl alcohol copolymer $(\mathrm{EVOH})$ that combines the gas barrier properties between layers of polyethylene. In passing, polyethylene sheets commonly used for conventional gas fumigation are unsuitable because of their carbon dioxide permeability. The following shows the scale of the insecticidal treatment facility used in each experiment session.

First experiment session:

Second experiment session:

Third experiment session:

Fourth experiment session:
$3 \mathrm{~m} \times 3 \mathrm{~m} \times 2 \mathrm{~m}$ (height)

$3 \mathrm{~m} \times 3 \mathrm{~m} \times 2 \mathrm{~m}$ (height)

$2.5 \mathrm{~m} \times 2 \mathrm{~m} \times 1.5 \mathrm{~m}$ (height)

$1.5 \mathrm{~m} \times 1.5 \mathrm{~m} \times 1.5 \mathrm{~m}$ (height) (fastener bag)

$5 \mathrm{~m} \times 3 \mathrm{~m} \times 2 \mathrm{~m}$ (height) 


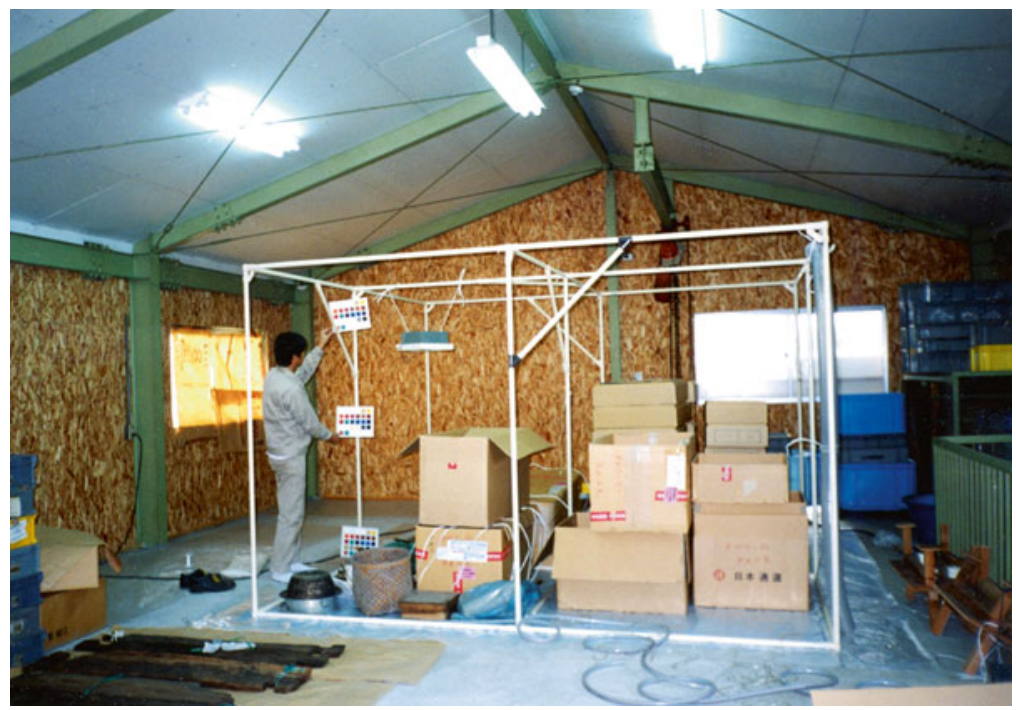

Fig. 1 Experimenting an enclosure-type insecticidal treatment system at the Gangoji Institute for Research of Cultural Property

These experiments were performed in order to confirm the setting of the carbon dioxide concentration in the initial treatment condition, adsorption of carbon dioxide by folklore artifacts, and effect on folklore artifact pigments. They also provided useful information pertaining to the process control necessary for the practical application of the method, such as air-tightness of the barrier cloth sheet, method of checking safety during processing, and cautions during the evacuation of gas. Consequently, the author was able to complete the instruction manual for insecticidal treatment using carbon dioxide.

\section{Development of Technologies Necessary for Applying the Insecticidal Treatment Method Using Carbon Dioxide at Museums}

After assuming a post at Minpaku in 2002, the author began working on the development of a system for applying the insecticidal treatment method using carbon dioxide that the procedures could be performed by museum staff. To prevent pest damage at Minpaku, the author introduced IPM (integrated pest management); examined methods of preventing insect damage to discover insect damage at the early stages and to perform insecticidal treatments; and ensured that these activities would link systematically with each other without causing isolation of individual activities (Sonoda 2007; Sonoda and Hidaka 2008, 2011). To this end, the author 


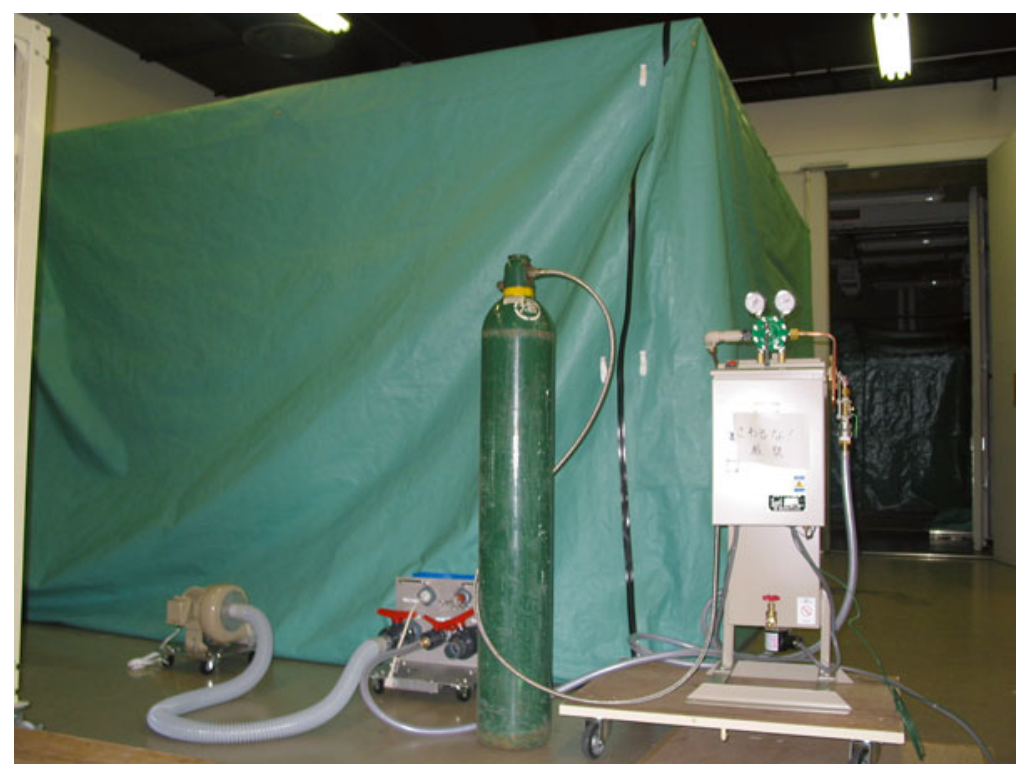

Fig. 2 Carbon dioxide treatment using a fastner bag

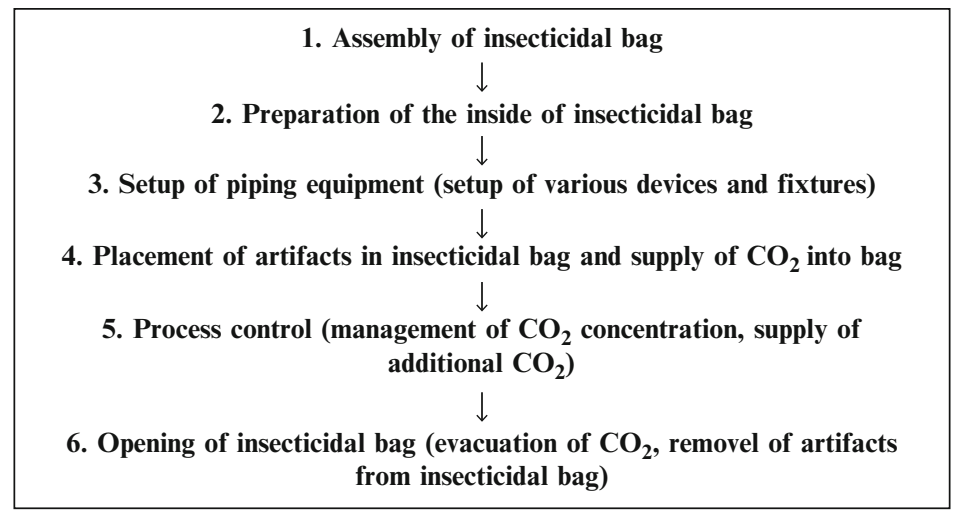

Fig. 3 Process flow of treatment using carbon dioxide

maximized the experience of successfully developing a carbon dioxide system that can be used for performing insecticidal treatments of a certain scale.

For the experiments that aimed at practical application of the insecticidal method, gas barrier cloth sheets were modified and a commercially available fastener bag $(1 \mathrm{~m}($ depth $) \times 1 \mathrm{~m}$ (width) $\times 1.5 \mathrm{~m}$ (height) $)$ was enlarged to a size measuring $4 \mathrm{~m}$ in depth, $4 \mathrm{~m}$ in width, and $2.5 \mathrm{~m}$ in height (Fig. 2). To enable the museum staff to perform the treatment, a manual was prepared, with special focus on providing safety precautions. Figure 3 shows the process flow chart created during the preparation of 


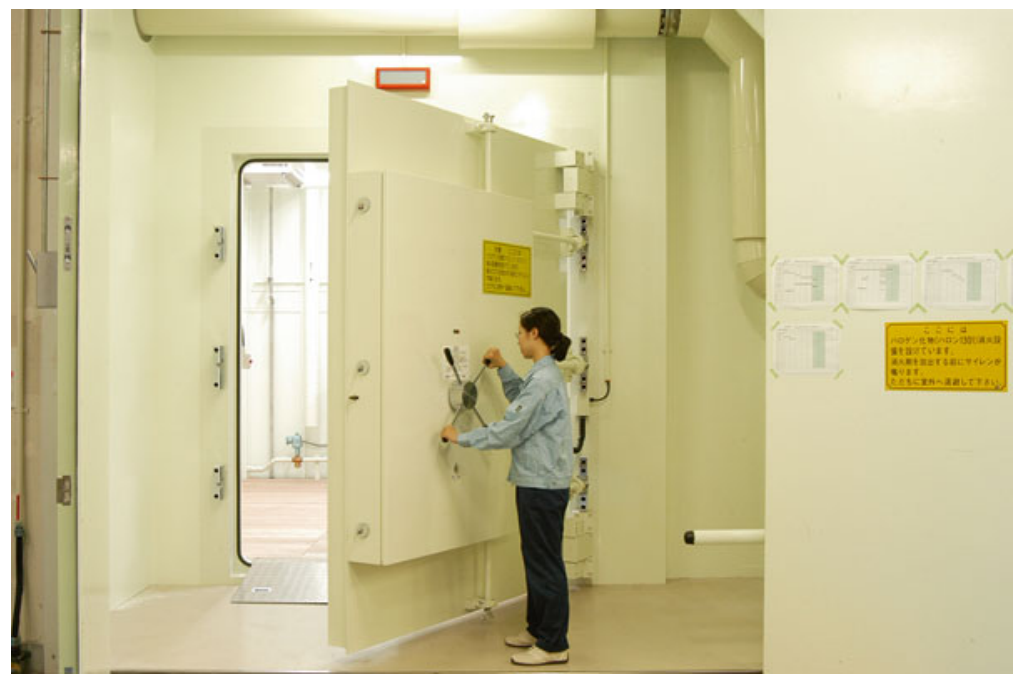

Fig. 4 Fumigation room capable of performing either gas fumigation, carbon dioxide treatment, or low-oxygen treatment

the instruction manual. In 2007, it was decided to modify the existing fumigation room $(5 \mathrm{~m}($ depth $) \times 4.3 \mathrm{~m}$ (width) $\times 3.6 \mathrm{~m}$ (height) $)($ Fig. 4$)$ and install a system capable of selectively performing gas fumigation using an ethylene oxide preparation, treatment using carbon dioxide, or low-oxygen treatment using nitrogen.

\section{Adaptability of the Insecticidal Treatment Method Using Carbon Dioxide in Large Fastener Bags}

After the successful installation of the system and a large fastener bag for insecticidal treatment using carbon dioxide at Minpaku, the author applied the technology to perform the treatment on a larger scale.

In 2013, the large tents (Fig. 5) in which large wooden boats and other items were stored were removed, and a multi-functional storage facility (Fig. 6) was constructed.

The multi-functional storage facility is equipped with a $\mathrm{CO}_{2}$-based/low-oxygen insecticidal treatment system and provided with a washing area (Fig. 7), so that it can be used to store wooden boats and also as a temporary storage site for cultural properties damaged by disaster. At the start of full-fledged operation of this facility at Minpaku, wooden boats were processed with the insecticidal treatment using carbon dioxide before storage. Using the permanently set up large fastener bag measuring $6.9 \mathrm{~m}$ in length, $2.8 \mathrm{~m}$ in width, and $2.2 \mathrm{~m}$ in height (Fig. 8), wooden boats were treated with carbon dioxide. The size of the permanently set up large fastener bag was determined in such a way that it would be large enough for $80 \%$ of the 


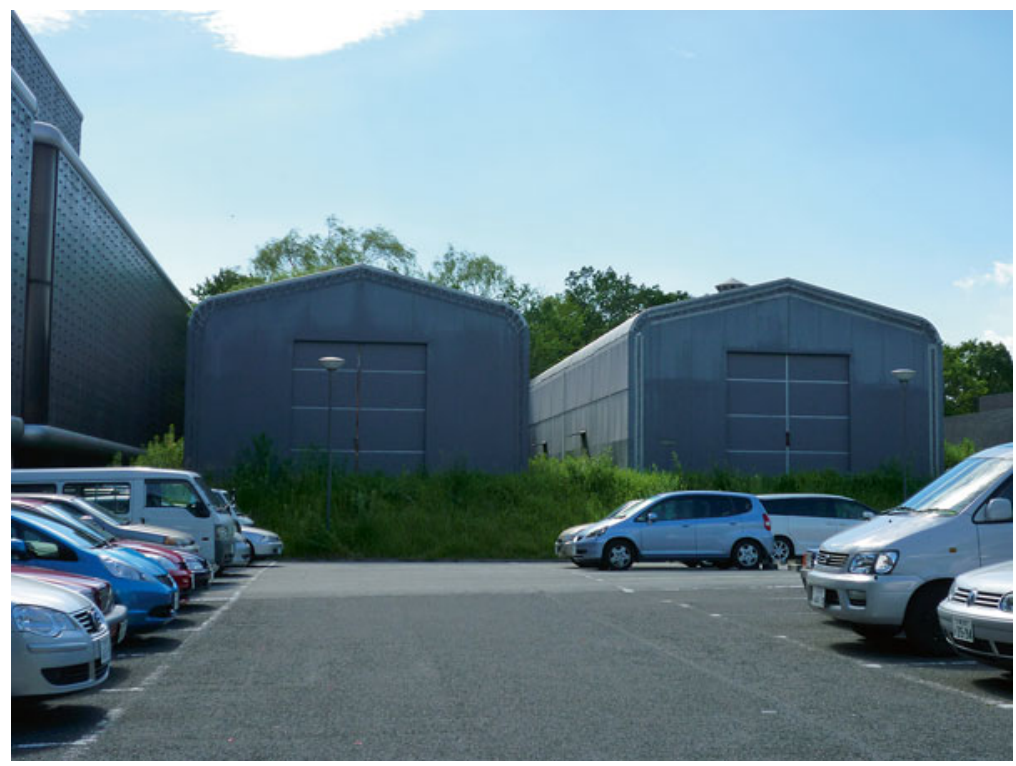

Fig. 5 Large tents storing wooden boats (before 2013)

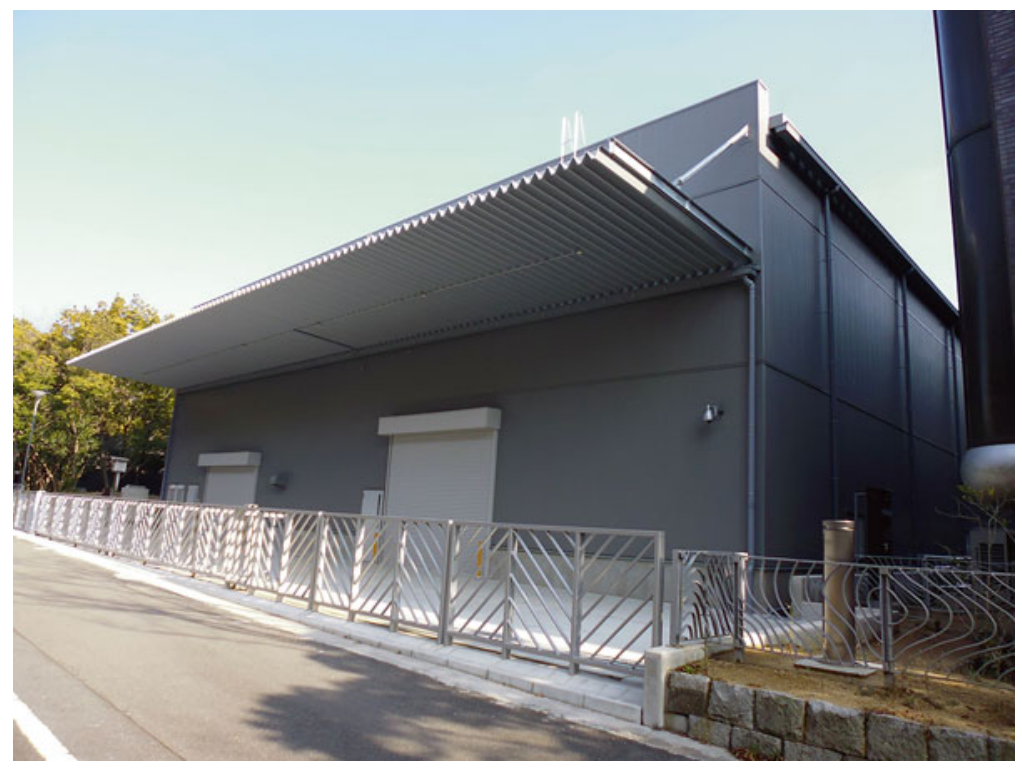

Fig. 6 Multi-functional storage facility storing wooden boats (after 2013) 


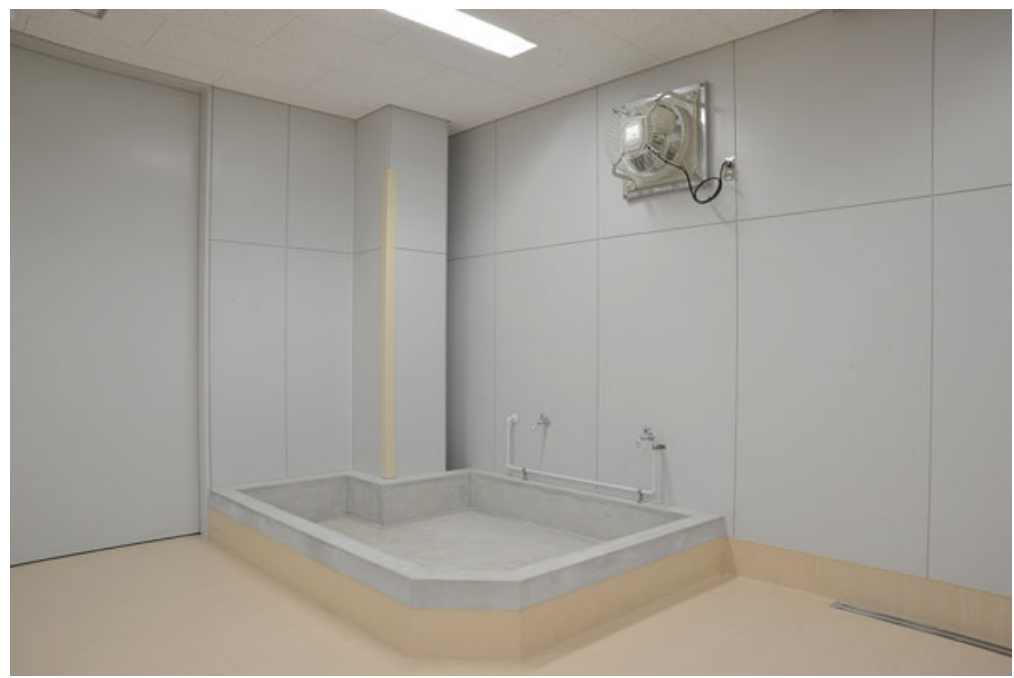

Fig. 7 Washing area

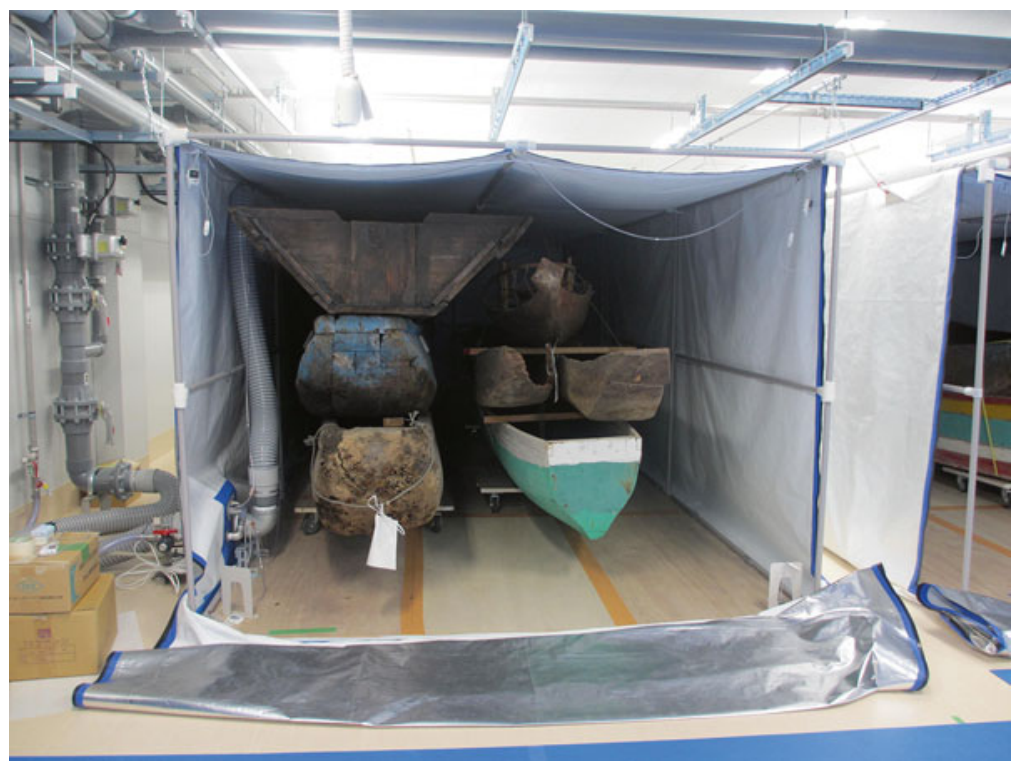

Fig. 8 Wooden boats treated with carbon dioxide in a permanently set up large fastener bag

wooden boats in storage. Large wooden boats that did not fit into this bag were treated with carbon dioxide in an enclosure-type insecticidal treatment bag measuring $11.5 \mathrm{~m}$ in length, $10 \mathrm{~m}$ in width, and $2 \mathrm{~m}$ in height (Fig. 9).

The data on actual insecticidal treatments using carbon dioxide are shown below. Figure 10 shows the concentration of carbon dioxide during the treatment in the 


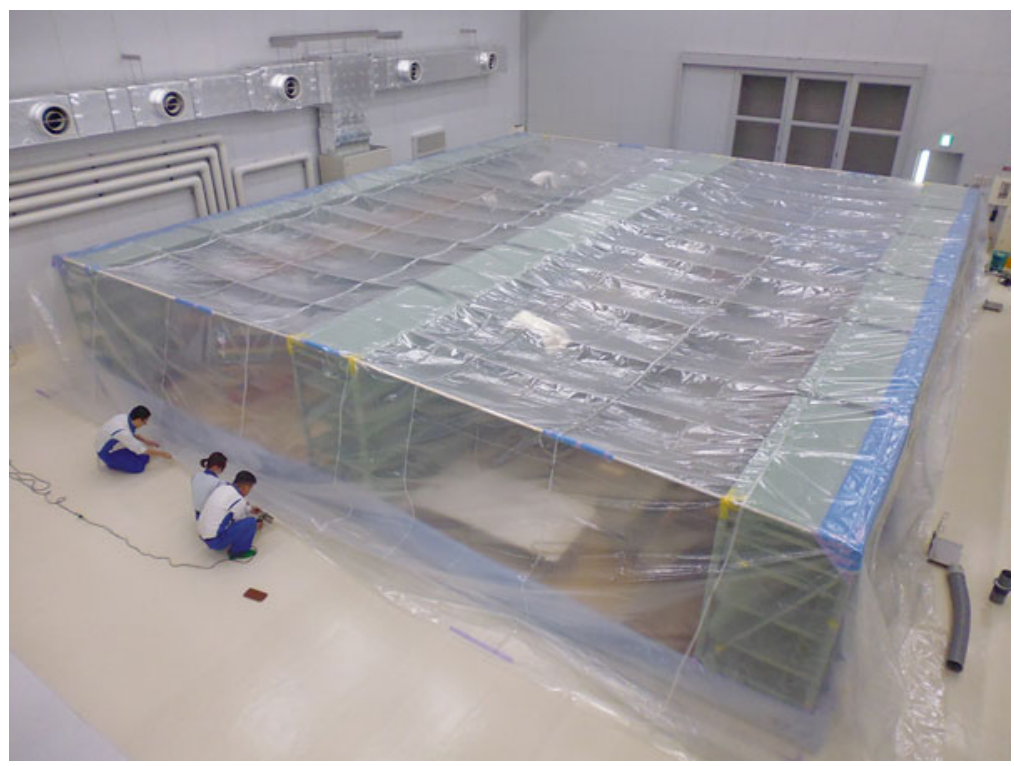

Fig. 9 Large wooden boats treated with carbon dioxide in an enclosure-type insecticidal treatment bag

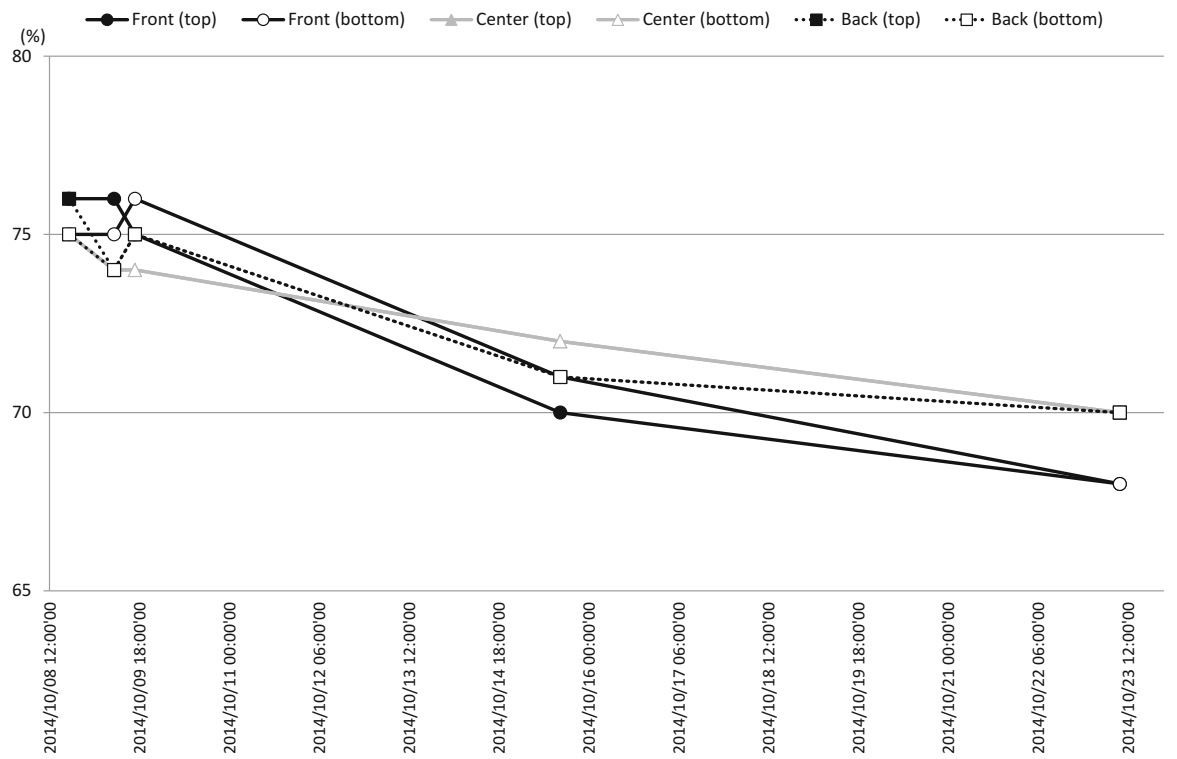

Fig. 10 Change in the concentration of carbon dioxide 


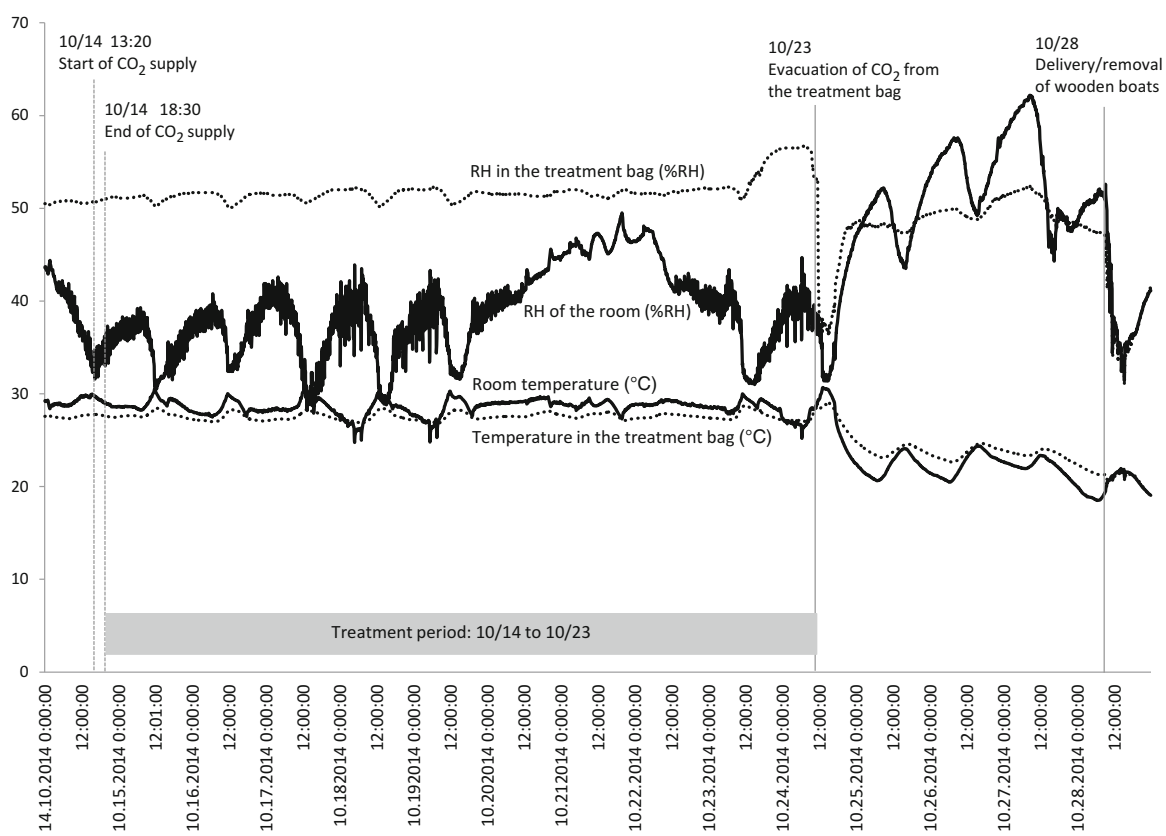

Fig. 11 Change in temperature and humidity during insecticidal treatment using $\mathrm{CO}_{2}$

Table 1 Results of assessment of the effect of insecticidal treatment using $\mathrm{CO}_{2}$

\begin{tabular}{l|l|l}
\hline $\begin{array}{l}\text { Location (Bag No. } \\
\text { 4) }\end{array}$ & $\begin{array}{l}\text { No. of } \\
\text { insects }\end{array}$ & Alive/dead \\
\hline Test insects (top) & 5 & $0 / 5$ \\
\hline Test insects (bottom) & 5 & $0 / 5$ \\
\hline Control & 5 & $5 / 0$ \\
\hline
\end{tabular}

enclosure-type bag measuring $11.5 \mathrm{~m}$ in length, $10 \mathrm{~m}$ in width, and $2 \mathrm{~m}$ in height. Figure 11 indicates change in temperature and relative humidity in the treatment bag. Table 1 summarizes the results of the assessment of the insecticidal effect. These data verify that insecticidal treatment using carbon dioxide can be performed on the scale described above.

\section{Future Topics}

This paper introduced a case of scientific research on preservation of museum collections, with focus on the development of an insecticidal treatment method using carbon dioxide. Since one of the preconditions for the development was that the treatment procedures could be performed by museum staff, close attention was paid to the assurance of worker safety at the development stage. However, there is a 
possibility that once workers become used to performing the procedures, they might pay less attention to safety management and neglect to check with the manual before executing the task. Thus, resolving this issue and providing safety education are major issues to be addressed in the future. Although the case introduced in this paper was successful, there are still some issues to overcome. For example, when carbon dioxide is supplied into the bag, the humidity in the bag decreases. So, there is a need to minimize the decrease in humidity. It is also necessary to develop a technology to achieve uniform distribution of carbon dioxide concentration in a large-scale treatment facility. There is a report that some cultural properties are damaged by pest insects, such as the longicorn beetle, against which treatment with carbon dioxide does not provide sufficient insecticidal effect. Thus, establishment of a methodology for the termination of these insects is another important issue.

As presented in the paper, research for improving the preservation and management of cultural properties is a very important and essential topic of scientific research on the preservation of museum collections.

Open Access This chapter is distributed under the terms of the Creative Commons AttributionNonCommercial 4.0 International License (http://creativecommons.org/licenses/by-nc/4.0/), which permits any noncommercial use, duplication, adaptation, distribution and reproduction in any medium or format, as long as you give appropriate credit to the original author(s) and the source, provide a link to the Creative Commons license and indicate if changes were made.

The images or other third party material in this chapter are included in the work's Creative Commons license, unless indicated otherwise in the credit line; if such material is not included in the work's Creative Commons license and the respective action is not permitted by statutory regulation, users will need to obtain permission from the license holder to duplicate, adapt or reproduce the material.

\section{References}

Kigawa, Rika, and Strang, Tom. 2011. Effects of fumigants and non-chemical treatments on DNA molecules and proteins: Case studies on natural history specimens and proteinaceous components of museum objects. In Integrated pest management for collections. Proceedings of 2011: A Pest Odyssey, 10 Years Later. London, 26-28 October 2011, ed. Peter Winsor, David Pinniger, Louise Bacon, Bob Child, Kerren Harris, Dee Lauder, Julie Phippard and Amber Xavier-Rowe, 115-122. Swindon: English Heritage.

Sonoda, Naoko. 2007. Conservation management system for tangible cultural resources at the National Museum of Ethnology, Osaka, Japan. In International symposium proceedings practice of conservation in museums - defining a vision for the practice of conservation in museums in the 21st century, ed. Conservation Division, Department of Cultural Properties, Tokyo National Museum, 97-103. Tokyo: Independent Administrative Institution, Tokyo National Museum.

Sonoda, Naoko, and Hidaka, Shingo. 2008. Between conservation and access: Implementation of integrated pest management at the National Museum of Ethnology, Osaka, Japan. In Conservation and access. Contributions to the London Congress 15-19 September 2008, The International Institute for Conservation of Historic and Artistic Works, ed. David Saunders, Joyce H. Townsend, and Sally Woodcock, 88-92. London: The International Institute for Conservation of Historic and Artistic Works. 
Sonoda, Naoko, and Hidaka, Shingo. 2011. Integrated pest management at the National Museum of Ethnology, Japan: Re-evaluation of preventive measures and control strategies. In Integrated pest management for collections. Proceedings of 2011: A Pest Odyssey, 10 Years Later. London, 26-28 October 2011, ed. Peter Winsor, David Pinniger, Louise Bacon, Bob Child, Kerren Harris, Dee Lauder, Julie Phippard and Amber Xavier-Rowe, 123-138. Swindon: English Heritage.

Strang, Tom, and Kigawa, Rika. 2011. Efficacy, effects, economics: The problem of distributing pest control advice to cover contingency. In Integrated pest management for collections. Proceedings of 2011: A Pest Odyssey, 10 Years Later. London, 26-28 October 2011, ed. Peter Winsor, David Pinniger, Louise Bacon, Bob Child, Kerren Harris, Dee Lauder, Julie Phippard and Amber Xavier-Rowe, 16-25. Swindon: English Heritage. 